\title{
KEPEMIMPINAN TRANSFORMATIF DI MADRASAH MINORITAS MUSLIM PAPUA BARAT
}

\author{
Ismail Suardi Wekke, Efa Rubawati, Siti Nurjannah \\ Email: iswekke@gmail.com \\ Sekolah Tinggi Agama Islam Negeri (STAIN) Sorong, Indonesia
}

\begin{abstract}
Madrasah as the oldest institution, constantly have to innovate for the sake of maintaining the quality of education. To meet the leadership of the madrasa has a share fully in developing and advancing the whole element of education, ranging from human resources to management. This research was descriptive qualitative approach to the leadership of Madsarah Ibtidaiyah Roudlotul Khuffadz of West Papua in extending the educational system through the transformative leadership patterns that are very dynamic and democratic, developing human resources simultaneously, process leadership (planning, organizing, moving and cordinatoring), encourages the occurrence of sincere work. Finally, other efforts are implemented memorizing the Qur'an, mapping the talents of interest of students, evaluation of each program and pay attention to accountability and transparency.
\end{abstract}

Keywords : Leadership Transformative, Quality Education, Muslim Minority

\begin{abstract}
Abstrak
Madrasah sebagai lembaga pendidikan tertua, senantiasa harus berinovasi demi menjaga kualitas pendidikan. Untuk memenuhi upaya tersebut, pimpinan madrasah mempunyai andil sepenuhnya dalam mengembangkan dan memajukan seluruh elemen pendidikan, mulai dari SDM hingga manajemen. Penelitian ini menggunakan pendekatan kualitatif deskriptif tentang pimpinan Madrasah Ibtidaiyah Roudlotul Khuffadz Papua Barat dalam mengembangkan sistem pendidikan melalui pola kepemimpinan transformatif yang sangat dinamis dan demokratis, mengembangkan SDM secara simultan, melakukan proses kepemimpinan (perencanaan, pengorganisasian, menggerakkan dan mengkordinasikan), mendorong terjadinya kerja ikhlas. Akhirnya, upaya lainnya adalah menerapkan hafalan al-Qur'an, memetakan bakat minat siswa, evaluasi setiap program dan memperhatikan akuntabilitas dan transparansi.
\end{abstract}

Kata Kunci: Kepemimpinan Transformatif, Kualitas Pendidikan, Muslim Minoritas

\section{Pendahuluan}

Madrasah di Papua Barat menjadi pilar dalam pencerdasan bangsa, secara historis madrasah merupakan salah satu lembaga pendidikan tertua di Indonesia, dan secara kuantitatif madrasah juga mencapai pelosok negeri (Supiana, 2008; Wanggai, 2012). Meskipun dari sekian banyak madrasah tersebut tidak semuanya dalam kondisi ideal, namun madrasah memiliki posisi sentral dalam turut mendidik generasi penerus bangsa. Oleh karena itu, bagusnya kualitas pendidikan di madrasah akan melahirkan generasi yang mampu memerankan diri sebagai pemimpin umat, masyarakat dan bangsa. Sebaliknya apabila kualitas pendidikan di madrasah tidak bagus maka kemungkinan mereka untuk berperan dalam percaturan bangsa akan makin kecil (Furchan, 2004). Pembaruan sistem pendidikan madrasah kini menjadi sebuah kebutuhan guna peningkatan kualitas untuk mencapai madrasah unggulan. Dimana unsur tradisional perlu senantiasa dipertahankan untuk diintegrasikan dengan unsur modern (Lukens-Bull, 2001).

Kualitas pendidikan bukan sesuatu yang terjadi dengan sendirinya, karena merupakan hasil dari suatu proses pendidikan, jika suatu proses pendidikan berjalan baik, efektif dan efisien, maka terbuka peluang yang sangat besar memperoleh hasil pendidikan yang 
bermutu (Supiana, 2008). Mutu pendidikan mempunyai kontinum dari rendah ke tinggi sehingga berkedudukan sebagai suatu variabel, dalam konteks pendidikan sebagai suatu sistem, variabel kualitas pendidikan dapat dipandang sebagai pilar yang didukung oleh banyak faktor seperti kepemimpinan (Mahmood, 2011), iklim organisasi (Wekke, 2012b), kualifikasi guru, anggaran (Wekke, 2013), kecukupan fasilitas belajar dan sebagainya (Munjin, 2013). Sehingga faktor kepemimpinan menjadi bagian yang menggerakkan semua unsur dalam peningkatan mutu madrasah. Kepala Madrasah menjadi pengambil kebijakan dan sekaligus memutuskan langkah-langkah dalam implementasi kualitas pendidikan yang dapat membentuk madrasah unggulan.

Dengan demikian, maka perlu ada sinkronisasi antara pembaruan sistem pendidikan dengan sistem kepemimpinan. Inovasi pendidikan dalam sistem pembelajaran maupun hal lain yang menunjang mutu sebuah madrasah terlahir dari sebuah sistem kepemimpinan transformatif. Inovasi dalam dunia pendidikan tidak terlepas dari sistem, kebijakan dan teknologi. Ketika kepala Madrasah melakukan sebuah inovasi pendidikan dan telah melakukan kebijakan yang diterapkan dalam sebuah sistem manajemen sekolah dan didukung oleh teknologi akan meningkatkan mutu madrasah, baik dalam sumber daya manusia maupun manajemen.

Sebagai bagian utama, topik kepemimpinan dalam peningkatan mutu pendidikan, telah dijadikan perhatian penelitian mengenai hal tersebut diantaranya penelitian mengenai kepemimpinan transformasional pendidikan berbasis manajemen total kualitas, penelitian ini lebih menitik beratkan pada kualitas manajemen pendidikan (Bukhori, 2010). Berbeda dengan fokus penelitian tersebut, kajian ini mengkhususkan pada kepemimpinan transformatif dalam hal penentuan kebijakan yang lebih kecil gaungnya dibanding sebuah manajemen. Ada pula penelitian mengenai pelaksanaan kepemimpinan transformatif kepala sekolah dan perannya bagi kinerja guru (Andari, 2012) Persamaan dengan penelitian ini, yakni meneliti kepemimpinan transformatif kepala sekolah untuk peningkatan kualitas sekolah atau madarasah. Namun berbeda pada sasaran atau pengaruh dari kepemimpinan transformatif tersebut, jika Reni lebih khusus terhadap kualitas dan kinerja Guru PAI, sementara pada artikel ini, akan mengkaji dampaknya terhadap siswa maupun guru. Selain itu penelitian mengenai Roudlotul Khuffadz telah dilakukan sebelumnya, namun fokus penelitiannya pada pendidikan pesantren serta hubungannya dengan kemampuan kewirausahaan santri (Wekke, 2012), integrasi kurikulum (Wekke, 2011). Adapun penelitian tentang madrasah berkaitan dengan pendanaan sekolah (Merry, 2007), pendidikan multikultural (Gunawan, Ketut \& Rante, Yohanes. 2011), pembelajaran bahasa Arab (Wekke, 2015) dan masyarakat madani (Pohl, 2006). Sementara dalam artikel ini, penulis secara khusus mengidentifikasi pendidikan formal yakni madarasah ibtidaiyahnya serta dari aspek kepemimpinan transformatif kepala madrasah. Dengan demikian, artikel ini secara khusus akan mengkaji pola kepemimpinan madrasah minoritas, Papua Barat.

\section{Pembaruan Madrasah dan Pola Kepemimpinan}

Kepala madrasah sebagai figur kunci dalam mendorong perkembagan dan kemajuan madarasah. Kepala madarasah, selain meningkatkan tanggung jawab dan otoritasnya dalam kebijakan yang kemudian dituangkan menjadi programprogram sekolah, kurikulum serta keputusan, juga bertanggung jawab untuk meningkatkan akuntabilitas, keberhasilan siswa serta keberhasilan programnya (Eius Karwati, 2013). Mengingat pentingnya tugas dan fungsi kepala madrasah, pembaruan pola kepemimpinan menjadi sebuah kebutuhan, karena pendidikan pada hakekatnya sesuatu yang dinamis dan mengikuti perkembangan, yang harus 
disesuaikan dengan kondisi kekinian. Pemimpin yang masih menggunakan pola kepemimpinan tradisonal tidak memiliki batas territorial maupun tanggung jawab yang jelas (Aunur Rohim, 2013), sehingga pola kepemimpinan kepala madrsah masih mempertahankan pola tradisional dengan tidak menerima pembaruan, maka akan terjadi pergeseran nilai kepemimpinan itu sendiri dalam bidang pendidikan sekarang dan yang akan datang. Dengan mengikuti perkembangan yang ada, maka pola kepemimpinan pun mengalami pembaruan selaras dengan pembaruan dalam sistem pendidikan.

Berdasarkan tugas dan fungsi kepala madrasah, maka pembaruan pola kepemimpinan seharusnya terjadi pada beberapa hal (Mulyasa, 2007), ini berbanding lurus dengan temuan yang penulis dapatkan pada pola kepemimpinan kepala madrasah di MI Roudlotul Khuffadz.

a. Sebagai desainer, kepala MI Roudlotul Khuffadz membuat rencana dengan memberikan kesempatan untuk terciptanya diskusi menyangkut isu dan permasalahan di seputar madrash dengan melibatkan berbagai komponen terkait yakni guru, tenaga kependidikan dan admistrator secara demokratis. Hal ini dapat dipahami bahwa dalam mengambil keputusan, kepala madrasah menerima masukan dan saran dari para anggotanya, sehingga menghasilkan keputusan yang paripurna. Ini merupakan hal baru, karena pada kepemimpina sebelumnya belum pernah dilakukan, pengambilan keputusan dilakukan sepihak, tanpa menerima masukan dan saran dari pihak terkait.

b. Sebagai evaluator maka kepala madrasah harus melakukan langkah awal, yaitu melakukan pengukuran seperti kehadiran, kerajinan dan pribadi guru, tenaga kependidikan, administrator sekolah dan siswa. Kepemimpinan transformatif yang dilakukan oleh kepala MI Roudlotul
Khuffadz adalah dengan melakukan evaluasi terhadap data-data hasil pengukuran tersebut. Adapun evaluasi yang bisa dilakukan, antara lain terhadap program, perlakuan guru terhadap siswa, hasil belajar, perlakuan belajar, perlengkapan belajar serta latar belakang guru. Semua ini dilakukan guna peningkatan SDM guru dan siswa, yang sebelumnya belum pernah dilakukan. Hal inipun baru diterapkan pada kepemimpinan MI Roudlotul Khuffadz saat ini, dikarenakan pemimpin sebelumnya tidak melakukan evaluasi secara menyeluruh, bahkan banyak hal yang tidak dilakukan evaluasi, sehingga tidak ada perbaikan guna penyempurnaan.

c. Sebagai manajer maka kepala madrasah harus memerankan fungsi manajerial dengan melakukan proses perencanaan, pengorganisasian, menggerakkan dan mengkordinasikan (planning, organizing, actuating, dan controlling). Dalam hal ini kepala MI Roudlotul Khuffadz merencanakan tujuan dan strategi untuk mencapai tujuan bersama. Mengorganisasikan yakni kepala MI Roudlotul Khuffadz memilih orang-orang yang kompeten dalam menjalankan pekerjaan dan mencari sumber daya pendukung yang paling sesuai. Menggerakkan adalah dimana kepala MI Roudlotul Khuffadz mempengaruhi orang lain agar bersedia menjalankan tugasnya secara sukarela dalam rangka mencapai tujuan yang diingikan. Mengontrol adalah kepala MI Roudlotul Khuffadz membandingkan apakah yang dilaksanakan telah sesuai dengan yang direncanakan atau belum. Jika belum sesuai, dievaluasi kembali jika ada kesalahan atau kekurangan dalam pelaksanaan program tersebut. Hal ini telah dilakukan oleh pemimpin sebelumnya, hanya saja pelaksanaannya kurang optimal, 
dikarenkan eksekusi yang tidak tepat. Sehingga kepala MI Roudlotul Khuffadz saat ini melakukan transofrmasi dengan pengoptimalan serta aktualisasi yang tepat sasaran.

d. Sebagai administrator maka kepala MI Roudlotul Khuffadz memiliki dua tugas utama. Pertama, sebagai pengendalian struktur organisasi, yaitu mengendalikan bagaimana cara pelaporan, dengan siapa tugas tersebut harus dikerjakan dan dengan siapa berinteraksi dalam mengerjakan tugas tersebut. Kedua, kepala MI Roudlotul Khuffadz pun melaksanakan administrasi substansif yang mencakup administrasi kurikulum, kesiswaan, personalia dan administrasi umum.

e. Sebagai leader maka kepala Madrasah harus mampu menggerakkan orang lain agar secara sadar dan sukarela melaksanakan kewajibannya secara baik sesuai dengan yang diharapkan pimpinan dalam rangka mencapai tujuan. Hal ini yang menjadi pembaruan pada MI Roudlotul Khuffadz, dikarenakan pada kepemimpinan sebelumnya dan bahkan banyak terjadi pada madrasah ataupun sekolah lainnya, yakni guru tidak bertahan lama mengajar pada satu instansi dikarenakan ketidaknyamanan lingkungan kerja serta pola kepemimpian kepala madrasah yang tidak mengakomodir keinginan anggotanya. Pada MI Roudlotul Khuffadz, kepala madrasah selalu merangkul guru, tenanga kependidikan dan administrator dalam semua hal, termasuk menerima masukan guna peningkatan madrasah. Hal ini yang membuat guru di MI Roudlotul Khuffadz nyaman mengajar, meskipun dengan upah seadanya, namun mereka ikhlas menjalaninya, karena merasa dihargai dan dibutuhkan oleh pimpinan. f. Sebagai fasilitator kepala madrasah harus terus mendorong proses pengembangan kemampuan seluruh staf secara terus-menerus dan berkesinambungan terhadap seluruh aktivitas sekolah. Kepala MI Roudlotul Khuffadz harus menyediakan sumber daya yang tampak seperti kebutuhan finansial, peralatan serta material lain, juga sumber daya yang tidak tampak seperti waktu dan kesempatan kepada guru, tenaga kependidikan dan administrator untuk membantu kemajuan sekolah.

g. Sebagai inovator maka kepala madrasah melaksanakan pembaruan terhadap pelaksanaan pendidikan di MI Roudlotul Khuffadz yang dipimpinnya, berdasarkan prediksi yang telah dilakukan sebelumnya. Contohnya inovasi berupa pembaruan kurikulum dengan memperhatikan potensi hafalan qur'an siswa, hingga dituangkan dalam sebuah aturan dalam pengambilan ijazah. Ada pula inovasi dalam sistem keuangan, dengan mempelajari kesalahan pimpinan yang terdahulu, maka kepala MI Roudlotul Khuffadz kini membuat sebuah sistem keuangan yang merupakan tabungan siswa dan bisa diambil kembali jika siswa yang bersangkutan lulus ataupun pindah dari MI Roudlotul Khuffadz. Hal ini dilakukan untuk mentaktisi keterlambatan dana BOS, sehingga guru, tenanga kependidikan dan administrasi bisa tetap menerima gaji setiap bulannya tanpa ada keterlambatan, begitupun kebutuhan proses belajar mengajar sehari-harinya.

h. Sebagai motivator kepala madrasah MI Roudlotul Khuffadz senantiasa memberikan motivasi kepada guru, tenaga kependidikan dan administrator sehingga mereka bersemangat dan bergairah dalam menjalankan tugasnya dalam rangka meningkatkan mutu pendidikan. 
Motivasi yang diakukan oleh kepala MI Roudlotul Khuffadz yakni dengan menujukkan adanya kepercayaan, mendorong proses pengambilalihan risiko dan menyampaikan informasi serta mempermudah partisipasi berbagai pihak dalam pengembangan MI Roudlotul Khuffadz.

i. Terakhir, sebagai liasion atau penghubung MI Roudlotul Khuffadz dengan dunia luar, kepala madrasah harus membawa ide baru ke madrasah yang diperoleh dan atau melihat perkembangan di dunia luar, terutama yang terkait dengan pengajaran dan pembeajaran. Kepala madrasah juga mengomunikasikan kemajuan dan hasil yang telah dicapai di madrasah kepada stakeholders di luar sekolah, salah satunya yakni Kementerian Agama Kabupaten Sorong yang secara tidak langsung sebagai penanggung jawab pendidikan agama.

Dari temuan menganai pembaruan kepemimpinan kepala MI Roudlotul Khuffadz sebagai telah dijelaskan, dapat penulis simpulkan bahwa pembaruan dalam pola kepemimpinan kepala madrasah sangat dibutuhkan dan implementasinya adalah dengan melihat situasi dan kondisi madrasah itu sendiri, dengan menggali potensi serta memiliki tujuan yang jelas disertai istiqomah, maka kemajuan MI Roudlotul Khuffadz guna menjadi madrasah unggulan dapat segera terwujudkan. Meskipun MI Roudlotul Khuffadz masih berusia dini, namun pembaruan pendidikan yang dilakukan sangat signifikan, hal ini senanda dan sejalan dengan pembaruan dalam pola kepemimpinan.

\section{Kepala Madrasah: Ujung Tombak Pengembangan Mutu}

Peningkatan kualitas madrasah ditentukan oleh Kepala Madrasahnya, karena di tangan kepala Madrasahlah segala kebijakan dan keputusan diambil yang akan mempengaruhi sistem pendidikan di madrasah tersebut. Tulisan ini, kembali mencoba untuk memberikan ulasan mengenai pentingnya kebijakan yang diambil oleh seorang pemimpin dalam hal ini Kepala Madrasah guna peningkatan kualitas madrasah yang dipimpinnya. Data dalam tulisan ini didapatkan dari Madrasah Ibtidaiyah Roudhatul Khuffadz, Kabupaten Sorong, Papua Barat.

\section{a. Hafalan Qur'an}

Salah satu kebijakan Kepala Madrasah yang termasuk dalam kepemimpinan transformatif adalah hafalan qur'an. Dikatakan transformatif, karena program hafalan qur'an ini belum atau tidak ada madrasah yang melakukannya. Mungkin ada beberapa madrasah yang memasukkan hafalan qur'an dalam materi pembelajaran, pada MI Roudhatul Khuffadz, bukan hanya masuk dalam materi (mulok) namun telah menjadi sebuah keharusan dan sebuah jaminan. Karena jika seorang murid telah lulus, maka syarat pengambilan Ijazah adalah dengan hafalan qur'an. Sebuah terobosan baru yang pernah ada dalam dunia pendidikan Islam dewasa ini, karena selain meningkatkan kualitas madrasah, hafalan qur'an juga sangat bermanfaat bagi murid itu sendiri. Selain itu, dalam hal tenaga pengajar, dengan perekrutan guru yang mempuni dalam bidangnya dan percaya sepenuhnya kepada guru tersebut untuk menggunakan metode pembelajarannya. Beberapa metode yang digunakan yang program hafalan qur'an:

- Dituntun membaca oleh guru pembimbing, kemudian ditunjuk satu persatu sambil dikoreksi hukumhukum bacaannya (tajwid), setelah itu diulang-ulang per ayat minimal 7 (tujuh) kali.

- Metode selanjutnya ditunjuk satu per satu, untuk menyetorkan hafalannya masing-masing kepada guru pembimbing.

- Hafalan dilakukan secara bertahap, untuk siswa tingkat 1 (satu) lebih ditekankan pada cara membaca, tingkat 2 (dua) sudah mulai menghafal 8 (delapan) surah mulai dari Surah at- 
Takasur hingga Surah Al-Kafirun, tingkat 3 (tiga) siswa ditargetkan telah menghafal 10 surah, begitupn seterusnya hingga pada tingkat 5 (lima) dan 6 (enam) para peserta didik sudah menghafal 1 juz bahkan lebih.

- Untuk siswa pada tingkat 1 (satu) dan 2 (dua) proses hafalan dilakukan setelah pulang sekolah. Hal ini berbanding terbalik dengan siswa pada tingkat 3 (tiga) hingga 6 (enam) yang proses hafalan dilakukan pada pagi hari sebelum dilakukan proses belajar dan mengajar.

- Selain itu, pengulangan dan evalusai hafalan senantiasa dilakukan oleh guru pembimbing agar lebih memantapkan hafalan peserta didik.

\section{b. Pemetaan Bakat dan Minat}

Bakat merupakan kemampuan dasar seseorang untuk belajar dalam tempo yang relatif pendek dibandingkan orang lain, namun hasilnya justu lebih baik. Bakat merupakan potensi yang dimiliki oleh seseorang sebagai bawaan sejak lahir. Sementara minat merupakan proses pengembangan dalam mencampurkan seluruh kemampuan yang ada untuk menyarankan individu kepada suatu kegiatan yang diminatinya. Persamaan bakat dan minat perlu dikembangkan melalui proses pembelajaran agar kemampuan dan keingainan yang ada, agar kemampuan dan keinginan yang ada dapat menjadi sesuatu yang nyata. Perbedaan antar keduanya, jika bakat adalah kemampuan alamiah atau bawaan untuk memperoleh pengetahuan atau ketrampilan yang relative bisa bersifat umum atau khusus. Minat lebih kepada keadaan seseorang yang menaruh perhatian pada sesuatu dan disertai keinginan untuk mengetahui, memiliki, mempelajari dan membuktikan.

Mengingat pentingnya perkembangan bakat dan minat peserta didik, maka MI Roudhatul Khuffadz memberikan waktu khusus untuk pemetaan bakat dan minat siswa yakni pada jum'at pertama di awal bulannya. Hal ini dilakukan untuk meningkatkan soft skill peserta didik, serta kemampuan dalam pendidikan umum lainnya. Meskipun MI Roudhatul Khuffadz berorientasi pada kurikulum Kementerian Agama RI, namun juga dilengkapi dengan kurikulum pendidikan umum dan keahlian. Diantara pemetaan bakat dan minat yang dilakukan dibagi dalam 3 (tiga) kelas, yakni Kelas Bahasa, Kelas Kesenian dan Kelas Pidato. Setiap kelas ditangani oleh guru pembimbing yang berkompeten dalam bidang masing-masing.

\section{c. Evaluasi Program}

Sebaik apapun program yang dilakukan dalam mengkesekusi kebijakan dari kepemimpinan transformatif yang dijalankan, namun jika tidak dilakukan evaluasi terhadap program tersebut, maka tidak akan terjadi perubahan dan perbaikan program. Oleh karena itu, Kepala MI Roudhatul Khuffadz menerapkan pengevaluasian program kerja dan kebijakan yang diterapkannya pada hari jumat disetiap awal bulannya. Setiap guru, administrasi dan bawahan lainnya melaporkan sesuai denga tupoksinya masing-masing dan jika ada permasalahan, maka akan dicarikan solusi terbaik secara musyawarah.

Kebijakan dan keputusan yang diambil oleh Kepala Madrasah senantiasa diikuti oleh guru-guru dan bawahan lainnya. Hal ini menunjukkan bahwa dalam mengambil keputusan dan memberikan kebijakan Kepala Madrasah selalu mempertimbangkan aspirasi dan kepentingan bawahannya, sehingga program-program yang dijalankanpun didukung oleh bawahannya.

\section{d. Akuntabel dan Transparan}

Seorang pemimpin dalam hal ini kepala madrasah, harus mampu mempertanggungjawabkan pengelolaan sumber daya serta pelaksanaan kebijakan yang dipercayakan kepada madrasah yang dipimpinnya untuk mencapai tujuan yang telah ditetapkan secara periodik. Selain itu seorang pemimpin harus memberikan informasi keuangan yang terbuka dan jujur kepada bawahan atau anggota organisasinya, karena para bawahan juga memiliki hak untuk mengetahui secara 
terbuka dan menyeluruh atau pertanggung jawaban dalam menglola sumber daya yang dipercayakan.

Pada MI Roudhatul Khuffadz, transparansi keuangan dilakukan setiap bulannya. Segala pemasukan dan pengeluaran melalui bendahara yang diawasi langsung oleh kepala madrasah dan kepala madrasah diawasi langsung oleh seluruh civitas MI Roudhatul Khuffadz sehingga transparansi keuangan sangat terjaga, begitupun dengan pertanggung jawaban anggaran sangat diperhatikan. Hal ini untuk menjaga kepercayaan semua pihak, agar tidak ada saling kecurigaan ataupun saling berburuk sangka.

\section{Kepemimpinan Transformatif Kepala Madrasah}

Artikel ini menggambarkan bahwa MI Roudhatul Khuffadz dalam hal kepemimpinan transformatif diimplementasikan dalam kaitan dengan siswa dan guru (termasuk didalamnya tenaga kependidikan dan administrator). Karena pendidik dan peserta didik merupakan komponen pendidikan yang mesti ada dalam pendidikan (Nizar, 2013) dari kedua komponen ini saling mempengaruhi satu sama lain guna peningkatan kualitas dan mutu madrasah.

\section{Guru}

Posisi pendidik (guru) dalam pendidikan berada pada posisi sentral dan penting, karena metode pembelajaran lebih penting dari materi belajar, akan tetapi peranan guru dalam proses belajar mengajar jauh lebih penting daripada metode pembelajaran itu sendiri (Nizar, 2013). Hal ini dapat dipahami bahwa, sebagai guru hendaknya bukan saja memperhatikan materi atau bahan ajarnya, namun metode serta peran aktif guru dalam proses belajar mengajar juga patut diperhatikan. Dalam hal ini, kepala MI Roudhatul Khuffadz mengambil kebijakan yang dituangkan dalam bentuk program sebagaimana telah penulis jelaskan sebelumnya, hal ini berdampak signifikan terhadap metode dan keaktifan guru di dalam kelas. Dari hasil pengamatan penulis, guru di MI
Roudhatul Khuffadz memiliki beberapa metode inovatif dalam proses belajar mengajar.

Selain itu, kebersamaan guru MI Roudhatul Khuffadz sangat erat, hal ini dikarenakan para guru senantiasa melakukan pertemuan rutin setiap bulannya. Ini berdampak baik bagi peningkatan kualitas SDM guru di MI Roudhatul Khuffadz. Pertemuan ini selain untuk meningkatkan ukhuwah Islamiyah diantara sesama guru, juga digunakan sebagai sarana saling sharing mengenai pembelajaran dan pemecahan masalah secara bersama. Karena tugas utama seorang guru atau pendidik, bukan hanya memberikan materi di dalam kelas semata, namun lebih dari itu, seorang pendidik harus mampu membentuk karakter siswa, menumbuhkan sifat-sifat baik dalam diri siswa serta menggali potensi dan bakat yang dimiliki setiap siswa. Mengingat pentingnya tugas dan fungsi guru, MI Roudhatul Khuffadz berupaya untuk senantiasa meningkatkan kualitas SDM guru melalui pelatihan dan pembimbingan secara berkala dan berkelanjutan. Hal ini membuat keaktifan, kreatifitas serta semangat guru diadaptasikan dalam proses belajar mengajar. Demikian pula dukungan teknologi informasi menjadi bagian dari media pembelajaran (Wekke \& Hamid 2013).

\section{Siswa}

Fungsi pendidikan yakni usaha untuk menumbuhkan atau menggali segenap potensi fisik, psikis, bakat, minat, talenta dan berbagai kecakapan lainnya yang dimiliki manusia, atau mengaktualisasikan (memunculkan) berbagai potensi manusia yang terpendam, kemudian mengembangkan dengan cara merawat dan memupuknya dengan kasih sayang (Abudin Nata, 2012). Hal inilah yang dipandang perlu bagi MI Roudhatul Khuffadz, sehingga berupaya untuk mewujudkannya dalam proses belajar mengajar. Sehingga dengan proses yang dilalui, membuat peserta didik merasakan dampak dari pengembangan potensi tersebut. Salah satu dampak yang terlihat jelas pada siswa yakni dengan 
diperolehnya beasiswa khusus penghafal al-Qur'an dari Kementerian Agama Kabupaten Sorong. Beberapa siswa di MI Roudhatul Khuffadz mendapatkan beasiswa tersebut.

Kementerian Agama dalam hal ini ikut berperan serta dalam pengembangan serta pembaruan pendidikan Islam. MI Roudhatul Khuffadz terus diberikan motivasi untuk membuat inovasi baru dalam sistem pendidikan, yang tentunya hal ini terwujud berkat pembaruan dan inovasi dalam pola kepemimpinan. Sebagaimana yang telah penulis jelaskan fungsi pemimpin sebagai liaison, dalam hal ini kepala madrasah telah menjadi penghubung antara madrasah dan pemerintah. Hal ini semakin menguatkan pola kepemimpinan yang dijalankan oleh kepala madrasah, karena keberhasilan kepemimpinan juga dengan memelihara hubungan dengan para "stakeholders", salah satunya adalah pemerintah (Siagian, 2010). Jika Madrasah Ibtidaiyah Roudhatul Khuffadz tetap istiqomah menjalankan program-program yang telah dicanangkan oleh kepala madrasah serta dijalankan oleh semua unsur dalam MI Roudhatul Khuffadz, maka Kementerian Agama akan menambah kuota beasiswa serta bantuan dari aspek yang lainnya.

Dengan adanya dukungan dari pemerintah ini, siswa MI Roudhatul Khuffadz berusaha untuk terus semangat dalam belajar, serta berupaya juga belajar mengamalkan apa yang dipelajari. Hal ini terlihat, para siswa yang penghafal al-Qur'an, mengulang hafalannya dimana saja dan kapan saja, tidak mesti hanya di dalam kelas saat proses belajar mengajar. Para siswa pun memiliki sikap yang baik kepada para guru, bukan hanya di sekolah saja, namun di luar sekolahpun sama, ini merupakan salah satu implikasi atau dampak dari kepemimpinan transformatif yang dilakukan oleh kepala madrasah dalam upaya peningkatan kualitas madrasah guna menuju madrasah unggulan.

MI Roudhatul Khuffadz berada dalam kelembagaan pesantren diintegrasikan dengan lembaga sekolah. Selanjutnya, untuk mendukung program-program sosial dibentuk pula panti asuhan. Sebagaimana dalam pendidikan Islam di minoritas muslim, bentuk kelembagaan seperti ini akan menjadi daya dukung dalam pengelolaan institusi (Wekke, Siddin, \& Kasop, 2017). Begitu pula dengan lingkungan yang menjadi bagian yang membantu pelaksanaan programprogram. Dengan demikian, adanya ptogram akademik akan terintegrasi dengan kegiatan lainnya dalam mengupayakan tercapainya program yang dicanangkan (Hong, dan Scardamalia, 2014) Termasuk usaha untuk mengumpulkan dana bagi menunjang pelaksanaan program-program pendidikan. MI Roudhatul Khuffadz berusaha untuk mengembangkan beberapa kegiatan kewirausahaan sehingga memperkuat pendanaan pesantren. Ini menjadi sebuah tuntutan agar fungsi ekonomi dapat membantu usaha dan kelancaran kegiatan (Talib, 2013; Merry, 2007).

Dari implikasi kepemimpinan transformatif yang dilakukan oleh kepala MI Roudhatul Khuffadz, terlihat dampak yang ditimbulkan sangat signifikan, ditunjukkan dengan adanya semangat dari para peserta didik, komitmen dari para pendidik, serta penegasan dari stakeholder lain. Apa yang saat ini dilakukan oleh MI Roudhatul Khuffadz belum mencapai sebuah kesempurnaan yang layak dikatakan sebagai madrasah unggulan, namun ada sebuah cita-cita dan tujuan yang mulia yakni berusaha untuk menuju sebagai madarasah unggulan dengan meningkatkan kualitas dan mutu madrasah.

\section{Kesimpulan}

Dari uraian di atas, maka dalam hal ini dapat disimpulkan sebagai berikut pertama pola kepemimpinan Kepala madrasah hendaknya bertransformasi dari pola tradisional. Dengan mengikuti perkembangan yang ada, maka pola kepemimpinan pun mengalami pembaruan selaras dengan pembaruan dalam sistem pendidikan. Kedua, Mengembangkan SDM madrasah supaya dapat menyelaraskan dengan keinginan kepala madrasah dalam 
menggerakkan roda kepemimpinannya. Ketiga, Mendorong SDM (guru dan staf madrasah) untuk dapat mendidik dan bekerja secara ikhlas meski upah yang diterima tidak banyak. Terakhir, Melakukan inovasi pendidikan mulai dari aspek kurikulum hingga penerapan metode baru dalam pendidikan.

\section{Daftar Pustaka}

Andari, Reni. 2012 "Pelaksanaan Kepemimpinan Transformatif Kepala Sekolah dan Perannya Bagi Kinerja Guru PAI di SMP Negeri 1 Kalasan", Tesis. Yogyakarta: UIN.

Bukhori, Ahmad. 2010. "Kepemimpinan Transformasional Pendidikan Berbasis Total Quality Manajement (TQM),"Tesis. Yogyakarta: UIN.

Daulay, Haidar Putra. 2014. Sejarah Pertumbuhan dan Pembaruan Pendidikan Islam di Indonesia. Jakarta: Kencana Prenada Media Group.

Fakih, Aunur Rohim. 2013. Kepemimpinan Islam. Yogyakarta: UII Press.

Furchan, Arief. 2004. Transformasi Pendidikan Islam di Indonesia. Yogyakarta: Gema Media.

Gunawan, Ketut \& Rante, Yohanes. 2011. Manajemen Konflik Atasi Dampak Masyarakat Multikultural di Indonesia . Jurnal Mitra Ekonomi dan Manajemen Bisnis, Vol. 2, No. 2, Oktober:212-224.

Hong, Huang-Yo dan Scardamalia, Marlene. 2014. Community Knowledge Assesment in a Knowledge Building Environment, Computers \& Education. Vol. 71. Februari:279288.

Lukens-Bull, Ronald A. 2001. Two Sides of The Same Coin : Modernity and Tradition in Islamic Education in Indonesia. Anthrophology and Education Quarterly, Vol. 32, No. 3, 350-372.

Mahmood, Saleha S. 2011. A Word about Ourselves. Journal of Muslim Minority Affairs. Vol. 31, No. 1 (March):1-3.
Merry, Michael S. 2007. Should the State Fund religious Schools?. Journal of Applied Pilosophy. Vol. 24, No. 3:255-270.

Mulyasa, E. 2007. Menjadi Kepala Sekolah Profesional. Bandung: PT Remaja Rosdakarya.

Nata, Abudin. 2012. Pemikian Pendidikan Islam dan Barat. Jakarta: PT. Raja Grafindo.

Nizar, Samsul. 2013. Sejarah Sosial dan Dinamika Intelektual Pendidikan Islam di Nusantara. Jakarta: Kencana Prenada Media Group.

Pohl, F. 2006. Islamic education and civil society: Reflections on the pesantren tradition in contemporary Indonesia. Comparative Education Review, $50(3)$.

Siagian, Sondang. P. 2010. Teori dan Praktek Kepemimpinan. Jakarta: Rineka Cipta.

Supiana. 2008. Sistem Pendidikan Madrasah Unggulan. Jakarta: Badan Litbang dan Diklat Departeman Agama RI.

Talib, Mohammad. 2013. The Moral Economy of the Madrasa: Islam and Education Today, Journal of Islamic Studies. Vol. 24. No. 2. 252-255.

Wanggai, Toni Victor M. Rekonstruksi Sejarah Umat Islam Di Tanah Papua. Jakarta: Badan Litbang dan Diklat Departemen Agama, 2009.

Wekke, Ismail Suardi, dan Sanusi Hamid. 2013. Technology on Language Teaching and Learning: A Research on Indonesian Pesantren. Procedia - Social and Behavioral Sciences Vol. 83: 585-589.

Wekke, Ismail Suardi. 2011. Pendidikan Islam Dan Pemberdayaan Masyarakat (Tinjauan Pendidikan Vokasional Pesantren Rodhotul Khuffadz Sorong. Jurnal Kajian Islam Hermenia. Vol. 10, No. 1 (Desember) 23-53.

Wekke, Ismail Suardi. 2012a. Pendidikan Agama dan Kewirausahaan Santri: Pesantren Roudhotul Khuffadz Sorong Papua Barat, Makalah (Disajikan dalam Temu Ilmiah 
Nasional Psikologi Fakultas

Psikologi Universitas Airlangga Surabaya 20-21 November).

Wekke, Ismail Suardi. 2012b. Amalan Pengajaran Dan Pembelajaran Bahasa Arab di Pesantren Immim Makassar, Indonesia. Fakulti Pendidikan Universiti Kebangsaan Malaysia.

Wekke, Ismail Suardi. 2013. Religious Education and Empowerment: Study on Pesantren in Muslim Minority West Papua. Jurnal Ilmu- ilmu Keislaman Miqot. Vol. XXXVII, No. 2 (Juli-Desember):374-395.

Wekke, Ismail Suardi. 2015. Arabic Teaching and Learning: A Model from Indonesian Muslim Minority. Procedia-Social and Behavioral Sciences, 191, 286-290..

Wekke, Ismail Suardi; Siddin, Siddin; \& Ibrahim Kasop. 2017. Pesantren, Madrasah, Sekolah, dan Panti Asuhan: Potret Lembaga Pendidikan Islam Minoritas Muslim. At-Tajdid: Jurnal Ilmu Tarbiyah, 6(1):127-143 